УДК 629.4.027

ПОРІВНЯННЯ ЕФЕКТИВНОСТІ ЗАСТОСУВАННЯ ГАЛЬМІВНИХ КОЛОДОК ТИПУ W14 ТА МТРУЗ 38.90.712205 НА ЛОКОМОТИВАХ ЗАЛІЗНИЦЬ УКРАЇНИ

Канд. техн. наук А.М. Зіньківський

СРАВНЕНИЕ ЭФФЕКТИВНОСТИ ПРИМЕНЕНИЯ ТОРМОЗНЫХ КОЛОДОК ТИПОВ W14 И МТРУЗ 38.90.712205 НА ЛОКОМОТИВАХ ЖЕЛЕЗНЫХ ДОРОГ УКРАИНЫ

Канд. техн. наук А.Н. Зиньковский

\title{
COMPARISON OF OF EFFICIENCY OF BRAKE PADS W14 AND MTPY3 38.90.712205 FOR LOCOMOTIVES OF RAILWAYS OF UKRAINE
}

Cand. of sciences A. Zinkivskyi

Проаналізовано використання різних типів гальмівних колодок на локомотивах. Визначено основні види несправностей, які виникають під час експлуатаџї̈ гальмівних колодок та встановлено причини виникнення цих несправностей. Запропоновано альтернативний вид гальмівних колодок, який має кращі експлуатаџійні властивості у порівнянні з гальмівними колодками, які вже експлуатуються на залізнииях Украӥни. Встановлено переваги застосування гальмівних колодок типу W14.

Ключові слова: гальмівні колодки, чавун, композитні матеріали, тяговий рухомий склад, гальмівні системи, залізниці України.

Проанализировано использование различных типов тормозных колодок на локомотивах. Определены основные виды неисправностей, возникающих при эксплуатачии тормозных колодок и установлены причины возникновения данных неисправностей. Предложен альтернативный вид тормозных колодок, который имеет лучшие эксплуатационные свойства по сравнению $c$ тормозными колодками, которые уже эксплуатируются на железных дорогах Украины. Установлено преимущества применения тормозных колодок типа W14.

Ключевые слова: тормозные колодки, чугун, композитные материаль, тяговый подвижной состав, тормозные системы, железные дороги Украины. 
The author identified the type of braking system used on the railway network of Ukraine, and set the main executive body of the braking system - the brake pads. A comparison of the two types of brake pads. The main fault of brake pads, which arise in the course of their operation. The causes of malfunctions of brake pads. The evaluation of the use of the brake pads on the main locomotives of railways of Ukraine. An alternative view of the brake pads - W14 production plant in Bydgoszcz, that have the best performance characteristics as compared to the brake pads MTRUZ 38.90.712205 who already operated on the railways of Ukraine. The advantages of the use of brake pads type W14.

Keywords: brake pads, cast iron, composite materials, traction rolling stock braking systems, railways of Ukraine.

Вступ. Безпека руху поїздів - головна вимога до функціонування залізничного транспорту України та світу в цілому. Ця вимога на залізницях України забезпечується широким спектром технічних та організаційних заходів, які спрямовані на дотримання безпечного руху поїздів, їх взаємодії з іншими учасниками руху на залізницях. Головною системою, що забезпечує безпеку руху, на рухомому складі та зокрема на локомотивах $\epsilon$ гальмівна система, яка спрямована на регулювання швидкості руху локомотивів та поїздів, а також їх зупинку в необхідному місці.

Постановка проблеми у загальному вигляді та іiї зв'язок із важливими науковими та практичними завданнями. Пневматична фрикційна система гальмування, що використовується на всіх типах рухомого складу залізниць України, передбачає установлення гальмівних колодок, які під дією

зусилля, створеного наповненими стисненим повітрям гальмівними циліндрами, притискаються до поверхні кочення коліс i, за рахунок створених сил тертя в місці контакту, створюють регульовану силу опору руху поїзда, що дає можливість зменшувати швидкість руху від будь-якого ії значення до

нуля. Отже, гальмування відбувається за

рахунок сил тертя, що виникає в площині контакту гальмівної колодки 3 колесом рухомого складу. При цьому відбувається зношення поверхонь, що контактують, i локомотивні гальмівні колодки за час експлуатації до заміни втрачають до 70 \% маси $[1,2]$.

На тяговому рухомому складі залізниць України переважно використовуються чавунні бандажні гальмівні колодки відповідно до вимог ГОСТ 30249-97 «Колодки гальмівні чавунні для локомотивів. Технічні умови», які у порівнянні з колодками з інших матеріалів себе добре зарекомендували. Однак $з$ розвитком технічного прогресу та підвищенням швидкостей руху посилилися вимоги до безпеки руху на залізничному транспорті. Останнім часом перед експлуатаційниками постало питання пошуку нових матеріалів для гальмівних колодок, який повинен забезпечити їх кращі експлуатаційні характеристики. У ході аналізу запропонованих варіантів було обрано гальмівні колодки типу W14.

Визначення мети та задачі дослідження. Метою статті $є$ обгрунтування застосування гальмівних колодок типу W14 для експлуатації на залізницях України.

Основна частина дослідження. Для забезпечення безпечних умов роботи працівників залізничного транспорту, безпосередньо пов'язаних 3 рухом поїздів, безпеки руху на залізничному транспорті та для нормального забезпечення перевезень залізничний рухомий склад, як i інші види транспорту, обладнується системою пневматичних гальм, виконавчим органом яких $\epsilon$ колодки, що притискаються до поверхні кочення коліс стисненим повітрям, яке надходить до гальмівних циліндрів через систему важелів. Основною i головною несправністю гальмівних колодок в експлуатації $\epsilon$ їх розтріскування та викришування, що призводить до передчасної заміни колодок на нові. Головною причиною таких несправностей $є$ низька якість матеріалу та низький контроль деталей, що виготовляються.

На локомотивах Укрзалізниці в теперішній час застосовують чавунні колодки виробництва Івано-Франківського ТРЗ типу МТРУЗ 38.90.712205 (рис. 1). Ці колодки відповідають ГОСТ 30249-97 та мають на своїй поверхні невеликі канавки для кращого відведення тепла та запобігання утворенню іскор. При спрацьовуванні колодок більш ніж на $25 \%$ ці канавки зникають i їх ефективність зникає. 


\section{Теплові двигуни}
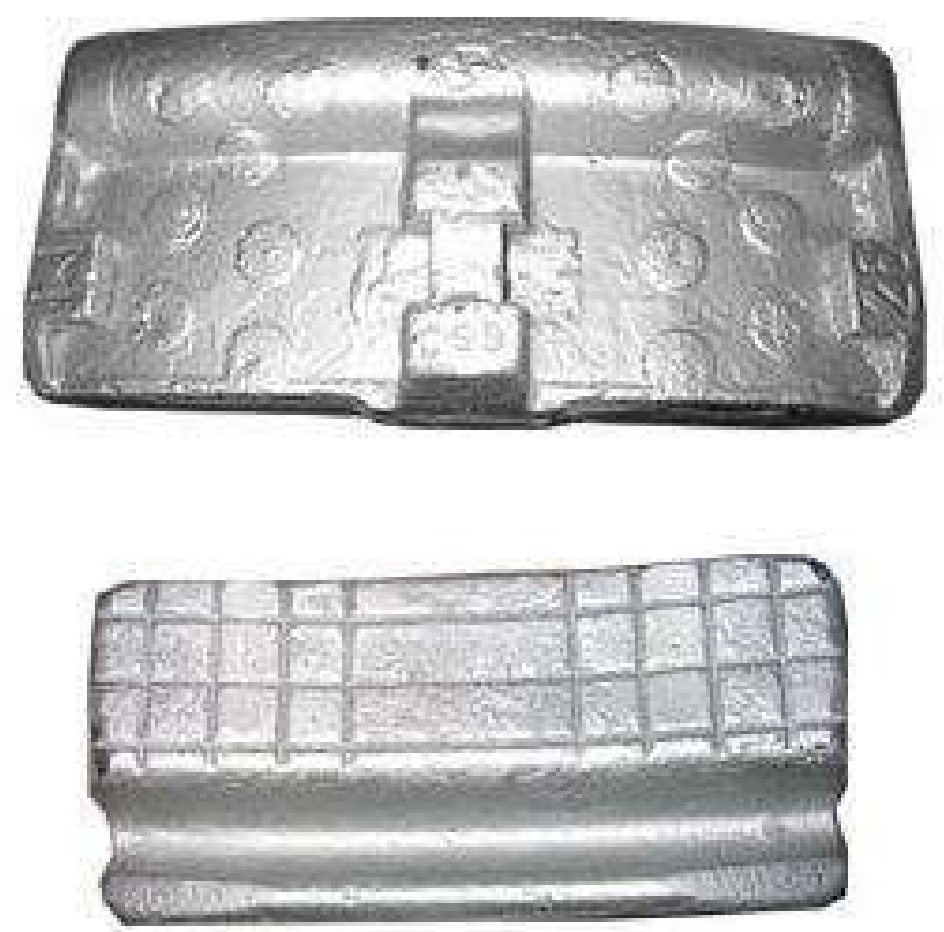

Рис. 1. Гальмівні колодки типу МТРУЗ 38.90.712205

Ці колодки себе позитивно зарекомендували, однак, під час експлуатації мали ряд несправностей, що впливали на безпеку руху залізничного транспорту. Серед таких несправностей можна назвати:

- викришування та відламування шматків колодки;

- утворення раковин та пустот у тілі колодки через неякісний процес лиття.

Альтернативою застосування цих колодок є гальмівні колодки типу W14 (рис. 2), розроблені на Чавуноливарному заводі в місті
Бдигощ. Вони відливаються 3 чавуну марки P10.

У своїй конструкції на площині контакту колеса та гальмівні колодки мають канавки, які призначені для усунення іскріння в момент притискання поверхонь тертя під час процесу гальмування. Оскільки канавки для гасіння іскор за своєю конструкцією досить глибокі, то i їх ефективність буде значно триваліша за часом при експлуатації. Основні характеристики колодки наведені в таблиці, на рис. 3 подано габаритні розміри цих колодок [3, 4].
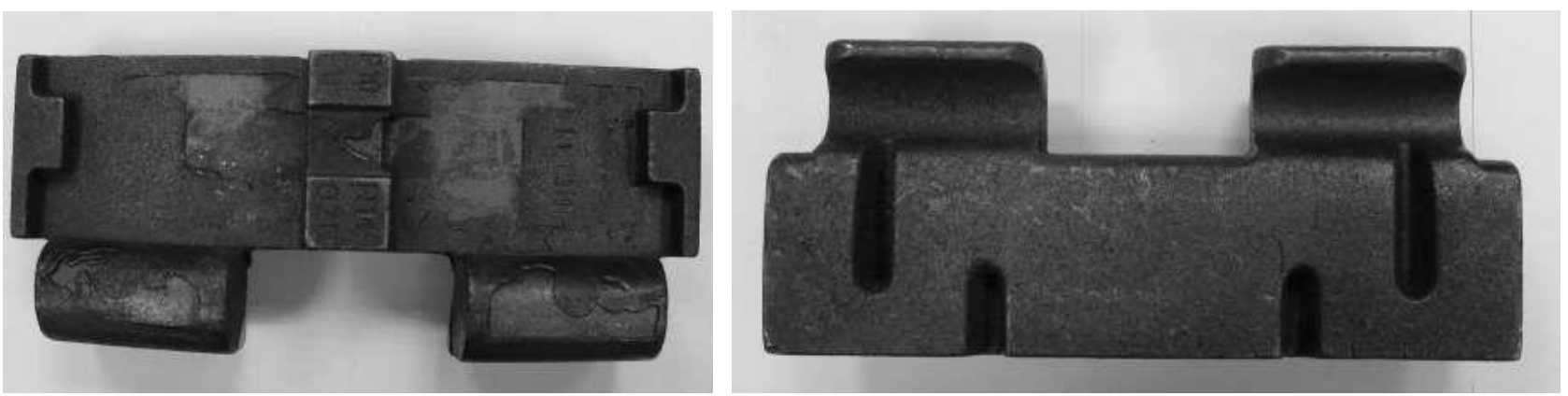

Рис. 2. Загальний вигляд гальмівної колодки типу W14 
Технічні характеристики гальмівних колодок типу W14

Таблиця

\begin{tabular}{|l|c|}
\hline \multicolumn{1}{|c|}{ Параметр гальмівної колодки } & Значення \\
\hline Матеріал & Чавун \\
\hline Марка матеріалу & Р10 \\
\hline Габаритні розміри, мм & $340 \times 145 \times 95$ \\
\hline Товщина нової колодки, мм & 40 \\
\hline Бракувальна товщина колодки, мм & 10 \\
\hline Ширина робочої поверхні, мм & 94 \\
\hline Маса нової колодки, кг & 13 \\
\hline
\end{tabular}

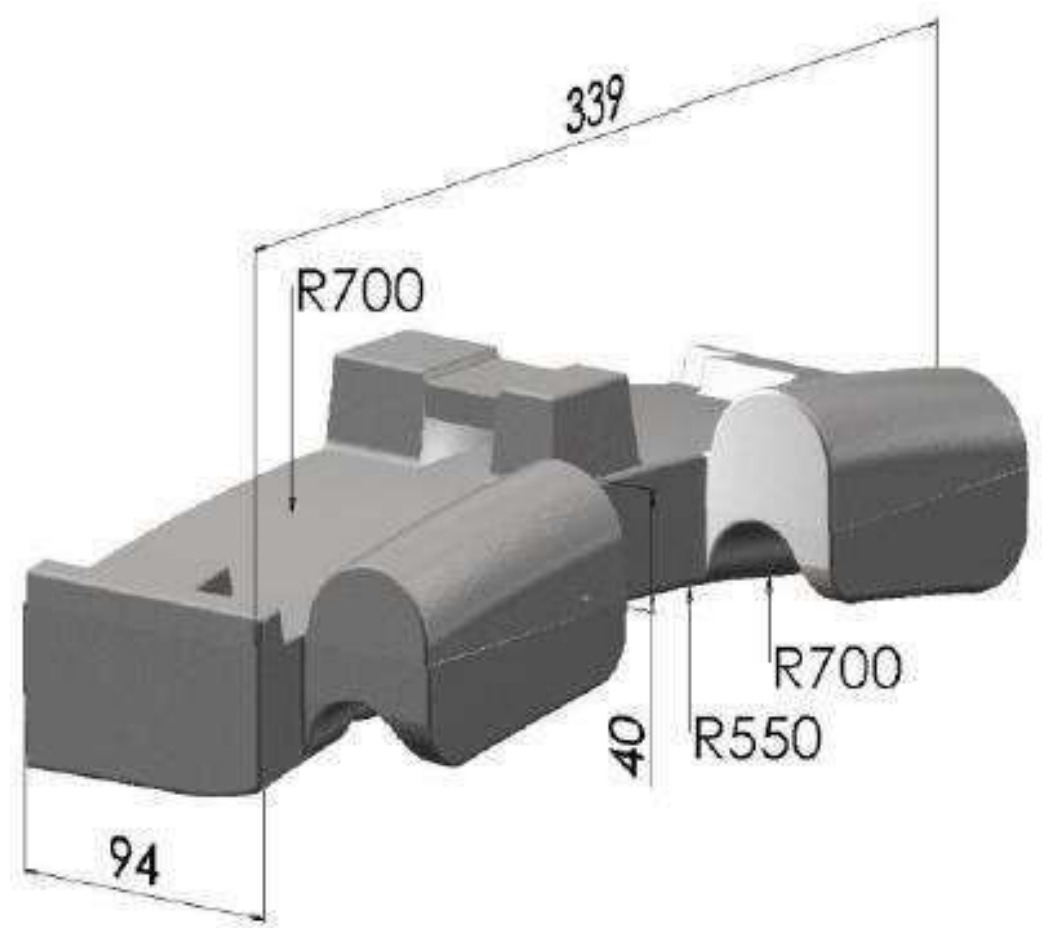

Рис. 3. Габаритні розміри гальмівних колодок типу W14

Реальний знос гальмівних колодок типу МТРУЗ 38.90.712205, виробництва ІваноФранківського ТР3 та колодок типу W14 виробництва заводу Бидгощ визначався під час порівняльних випробувань. Нові колодки обох типів установлювались на колісні пари різних візків одних i тих же локомотивів для можливості повного вирівнювання умов випробувань. Під час випробувань локомотиви експлуатувалися в штатному режимі без виникнення нештатних ситуацій та значних порушень функціонування колодок обох типів.
Колодки для перевірки широкого спектра застосування установлювались на тепловози та електровози різних серій, які працювали у всіх видах руху: маневровому, маневрововивізному, вантажному, пасажирському.

За даними, отриманими за результатами випробувань, було побудовано графік залежності питомого зносу гальмівних колодок обох типів від пробігу локомотивів (рис. 4). Установлено, що величина зносу гальмівних колодок вітчизняного виробництва в середньому на 14 \% вища, ніж закордонного. 


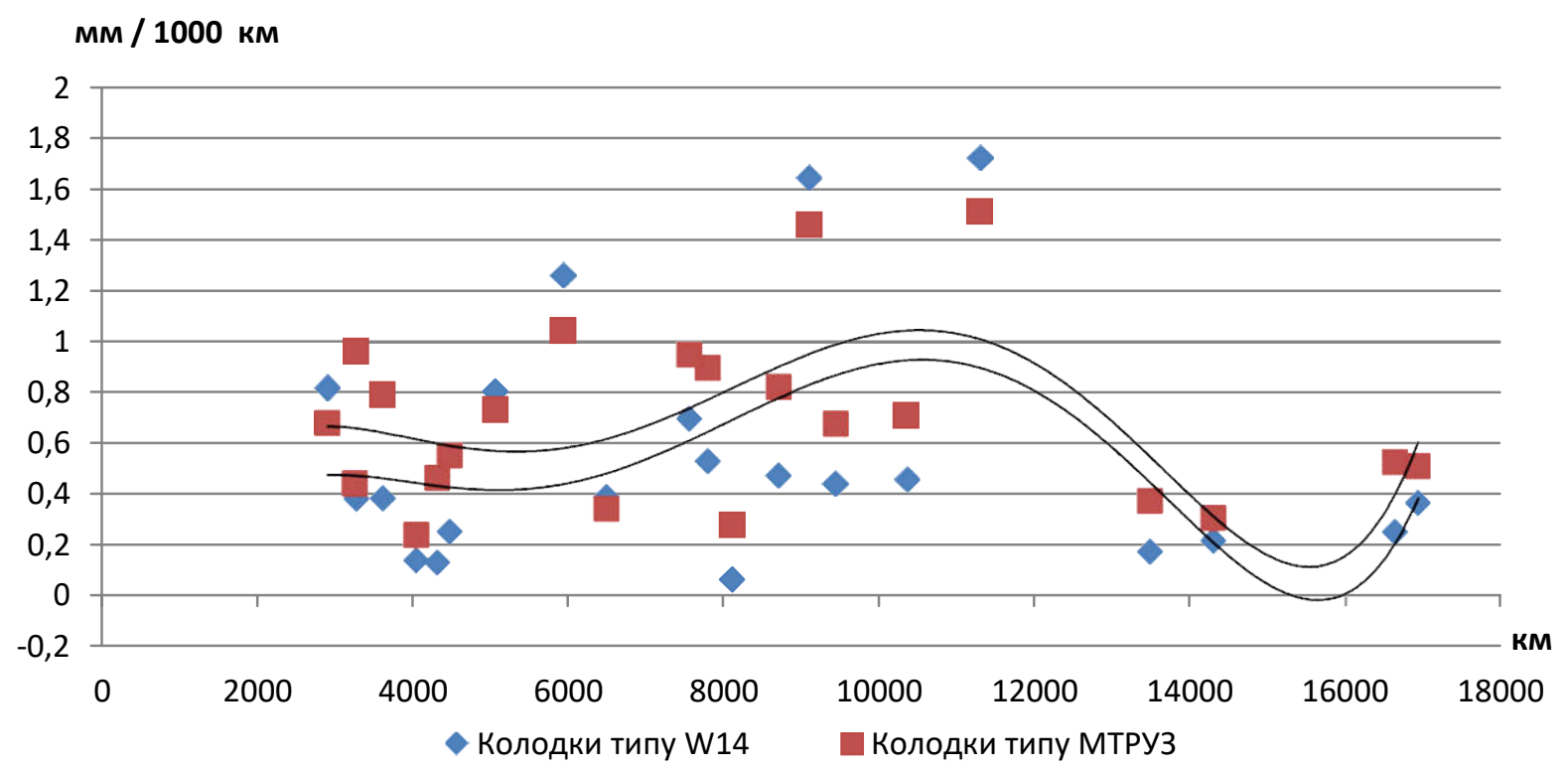

Рис. 4. Залежність питомого зносу гальмівних колодок від пробігу

\section{Висновки 3 дослідження:}

1. Застосування на локомотивах гальмівних колодок типу W14 забезпечує збільшення пробігу локомотива до їх заміни за рахунок зносу цього типу колодок на $14 \%$ у порівнянні 3 колодками типу МТРУз 38.90.712205.

2. Використання колодок типу W14 на локомотивах не спричиняє суттєвого збільшення величини зносу бандажів колісних пар у порівнянні з використанням гальмівних колодок типу МТРУЗ 38.90.712205.

3. Для отримання більш точних результатів досліджень і визначення повного ресурсу колодок та їх надійності необхідно продовжити експлуатацію колодок та розширити галузь їх застосування на більшу кількість серій локомотивів.

\section{Список використаних джерел}

1. Колодки тормозные чугунные для локомотивов. Технические условия [Текст]: ГОСТ 3024997. - [Введен 1999. - 01. - 01.]. - Минск: Межгосударственный совет по стандартизации, метрологии и сертификации, 1997. -9 с.

2. Красиков, Г.В. Повышение ресурса чугунных тормозных колодок локомотива [Текст] / Г.В. Красиков // Молодой ученый. - 2011. - №2, Т.1. - С. 35-38.

3. Odlewnię Żeliwa Bydgoszcz [Электронный ресурс]. - Режим доступа: http://www.odlewnia.com.pl/ru.

4. Інформація щодо виданих сертифікатів протягом квітня 2013 р. - травня 2013 р. державним підприємством “Дніпропетровський орган з сертифікації залізничного транспорту” [Текст] // Вісник сертифікації залізничного транспорту. - 2013. - № 3 - С. 37.

5. Тартаковський, Е.Д. Використання гальмівних колодок нової конструкції на залізницях україни [Текст] / Е.Д. Тартаковський, А.П. Фалендиш, Є.М. Шапран, Л.І. Залеський, А.Л. Сумцов // Зб. наук. праць Укр. держ. акад. залізнич. трансп. - Харків: УкрДАЗТ, 2014. - Вип. 145. - С. 100-104.

Рецензент д-р техн. наук, професор А.П. Фалендиш

Зіньківський Артем Миколайович, канд. техн. наук, доцент кафедри експлуатації та ремонту рухомого складу Українського державного університету залізничного транспорту. Тел.: 057-730-1999. E-mail: kumasiktem@ukr.net.

Zinkivskyi Artem, PhD assistant, Maintenance and repair of rolling stock. Tel. 057-730-1999.

Наукова праця здана до друку 05.11.2015 p. 